
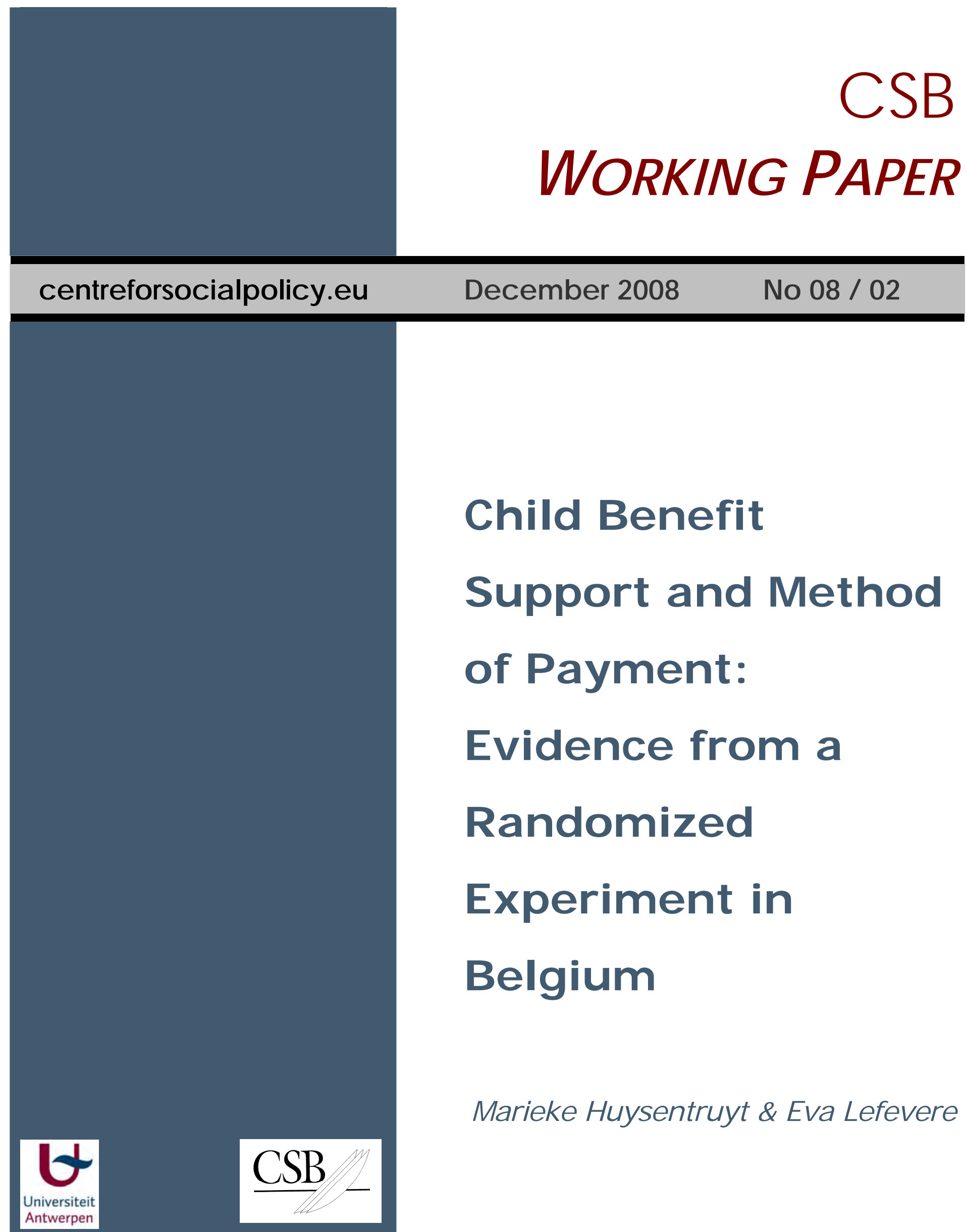

Marieke Huysentruyt \& Eva Lefevere

University of Antwerp

Heman Deleeck Centre for Social Policy

Sint J acobstraat 2

B - 2000 Antwerp

$\operatorname{fax}+32(0) 32755790$ 


\title{
Child Benefit Support and Method of Payment: Evidence from a Randomized Experiment in Belgium*
}

\author{
Marieke Huysentruyt \\ Department of Management, LSE \\ and \\ SITE, Stockholm School of Economics \\ Eva Lefevere \\ Centre for Social Policy, University of Antwerp
}

August, 2008

\begin{abstract}
We present evidence from a randomized field experiment explictly designed to shed light on the role of standard information, goal framed information, and decision task complexity in individuals' choice of payment method. The experiment encouraged 19,707 Clients of the Belgian National Office for Family Benefits to change from benefit payment by check to payment via direct transfer via a one-time mailing. The direct mailings multiplied the switching rate of these treated individuals (relative to the controls) by more than four times, showing that simply providing information can result in a very large behavioural change. Interestingly, foreigners were much more reponsive to the direct mailings than Belgians. Furthermore, simple, lowcost supplements to the standard information can amplify the magnitude of the behavioural responses. Adding both a flyer and a specific plan supplement to the standard letter not only yielded the largest effects on individuals' method of payment choice, but also appeared to speed up the decision to switch. We provide a simple, behavioural economics' interpretation to account for our results.
\end{abstract}

Keywords: Social security payments, Method of payment, Financial exclusion, Psychology and economics, Behavioural economics, Cues

\footnotetext{
${ }^{*}$ We are indebted to Johan Verstraeten (Belgian National Office for Family Benefits for Salaried Persons) for agreeing to collaborate in our experiment. We wish to thank Saskia De Jaegher, Béatrice Adriansens and Herman Van Wilderode and Chris Brijs in particular who patiently answered our many questions, showed strong interest in the project and made many useful suggestions. We are also thankful to Erlend Berg, Tim Besley, Bea Cantillon, Raj Chetty, David de Meza, Nada Eissa, Marc Gurgand, Justine Hastings, Wojcieh Kopczuk, Eric Maurin, Sendhil Mullainathan, Daniel Read, Karel Van den Bosch, Gerlinde Verbist and Ebonya Washington, who provided useful suggestions at various stages of this project. Financial support from the Research Foundation - Flanders (FWO) is greatly appreciated. All remaining errors are, of course, ours. Contact email address: m.e.huysentruyt@lse.ac.uk
} 


\section{Introduction}

Today, social security institutions feel increasingly pressed to make use of electronic payment methods when dispersing welfare benefits. Rapid banking sector modernization and recent, sharp increases in the cost of checks have notably contributed to this trend: in Belgium for instance, the price for issuing a check has more than tripled over the past five years. But also, the belief that people's decision to receive welfare benefits by check may in fact not be in their own best interests, and further that by encouraging welfare recipients to switch to automatic transfers, governments might too tip these people from the fringes into the financial mainstream, has in effect led several welfare programs today to prioritize the need to minimize transfer checks. Despite this, however, little is known about the reasons why such large shares of welfare beneficiaries at present fail to use electronic payment methods, how governments can really influence the choice of payment mode by these welfare beneficaries, and how this switch to electronic government transfers might impact consumer behaviour and poverty more generally. Whether government can effectively induce welfare recipients to switch payment method and at what 'true' cost remains an open, and important, empirical question. We present evidence from a large-scale experiment explicitly designed to shed light on these issues, and in particular the first and the second one.

In April 20007, the Child Benefit Office of the Belgian government (the socalled the 'National Office for Family Benefits for Salaried Persons') undertook to encourage its beneficiaries to switch to automatic government transfers via a major information campaign. The goal of the campaign was to inform people about a specific, newly introduced law, which specially protects child support benefits from outstanding debt claims even when deposited onto a bank account, and, exploiting this instance, to draw people's attention to the welfare gains more broadly from switching to electronic government transfers. This presented us with an ideal setting to examine empirically the role of information in welfare recipients' choice of payment mode. So we ask to what extent people currently stick to welfare checks simply because they are not fully aware of the gains from switching payment mode, and/or they find it difficult to implement that switch because of e.g. myopia, the task's complexity, a tendency to procrastinate or a status quo bias.

We essentially designed the campaign in collaboration with Belgium's 'National Office for Family Benefits for Salaried Persons' (henceforth, the National Office for Family Benefits), adapting the campaign to the format of a randomized field experiment. The experiment encouraged 19,707 beneficiaries (who at the time of the experiment were all receiving their child benefit via check) through a one-time mailing sent by the National Office for Family Benefits. These beneficiaries were randomly assigned to one of five different treatment groups (and one control group). All the treatment groups received a basic, informative letter that spelled out the gains from payment via transfer with a particular emphasis on the newly introduced law. Some groups also received a supplement, which contained independently randomized "psychological" features that were motivated by specific frames and cues shown to work in labs and in theory, but from a normative standpoint ought to have no impact. The supplement was a flyer that differentially framed the government's message, emphasizing either the gains from switching to payment on a bank account or the losses from failing to switch. Some groups additionally received not only a flyer but also a step-by-step 
plan on how one should proceed to change the benefit payment method.

Our research design combined with individual level data from administrative records on payment mode allows us to provide evidence on how different kinds of information affect people's payment method choice. We identify the effects of the presentation and informational details of the campaign on individuals' switching decision and the timing of this decision (early versus late), and use individual level data to examine whether the campaign succeeded in influencing the switching decision of those individuals whose decision we might expect to be most difficult to sway.

Four main results stand out. First, treated beneficiaries were more than four times as likely to switch payment method than control beneficiaries. Furthermore, one out of four treated beneficiaries changed payment mode. We also evidence no significant behavioural response to the law prior to the campaign, supporting our central claim that (in our context) information matters. Second, we also show how various details of the information provided can significantly shape the size of the behavioural response. Supplying decision-makers with easy-to-comprehend information in the form of a flyer (over and above to the standard, informative letter) raised beneficiary compliance with 2 percentage points relative to the standard, informative letter alone. Furthermore, supplementing the standard letter with a flyer ánd a specific, step-by-step plan raised beneficiary compliance even more. The impacts of the supplements were large in relative terms (raising the likelihood of switching by 10 to 18 percent after 2 months), though somewhat small in absolute terms (an increase of 2 to 4 percentage points on a base of 24 percent for the standard letter group only). Third, the letter plus flyer plus specific plan treatment not only produced the largest effect on beneficiaries' switching decision, it also noticeably raised the speed of compliance. The implementation plan thus appears to have helped mitigate people's tendency to procrastinate. Finally, foreign welfare recipients were not only more likely to switch, they were also significantly more responsive to the direct mailings than Belgians. This suggests not only that complexity and information costs represent important hurdles to the use of electronic payment methods, but also that these costs are apparently greater for those with language barriers and immigration concerns.

Our results show that government can reap considerable efficiency gains (savings) simply by adopting more effective social marketing strategies. This insight stands in stark contrast with a tendency by government agencies to underappreciate the potential impact of marketing as a "superficial" yet highly efficient intervention. The positive impact on government expenditures, however, is not the sole reason why our experiment especially matters. Various strands of research indicate that switching payment method can yield significant consumer gains as well. A large literature on mental accounting, for instance, has argued that people tend to treat money in different mental accounts differently (see e.g. Thaler, 1990, Thaler, 1999). In particular, there is substantial evidence that shows that an individual's marginal propensity to spend a euro in the current bank account tends to be lower than the marginal propensity to spend a euro in cash. Accordingly, switching payment method could also significantly raise consumer welfare via its positive impacts on household savings, ${ }^{1}$ and personal finance management more broadly. Since many of the wel-

\footnotetext{
${ }^{1}$ Berg (2007) presents evidence on a strong positive effect of the electronic payment of social grants on household's savings decisions in South Africa.
} 
fare recipients paid by check are also unbanked, the decision to switch to electronic government transfers might also be instrumental to becoming part of the financial mainstream.

Finally, our findings show how information can produce large effects on individuals' behaviour, even in an important domain as personal finances. When observing behavioural differences between people from different socio-economic backgrounds, these differences are often attributed to distinct individual characteristics. This paper, by contrast, draws attention to the power of information, as well as simple, purportedly minor situational cues. ${ }^{2}$ It draws attention to the informational "details," and at the same time, considering the still relatively small increments in compliance achieved by the flyers and implementation plans, urges us to experiment more with various such details.

The remainder of the paper proceeds as follows. Section 2 provides more detail on the experimental manipulations or treatments. Section 3 describes the child benefit programme, the design of the experiment and the data. Section 4 discusses the empirical results. Section 5 concludes.

\section{Treatments}

Each "Client" of the National Office for Family Benefits paid by check (at the time of the information campaign) was sent one of five different mailings. We detail the features below along with the prior work and hypotheses underlying these treatments. Our motivation stems primarily from findings in psychology and marketing that are most closely related to theories of consumers' information acquisition process. We discuss alternative interpretations of treatment effects in Section 4 .

Our first treatment group simply received a standard, informative letter drafted by the National Office for Family Benefits. The letter starts by explaining to the reader that since January 2007 a new Belgian law has come into force, which extends a special protection from outstanding debt claimants to government transfers, including child benefit, when paid directly onto a bank account ${ }^{3}$. Prior to this law, such protection was only guaranteed for benefits paid by check. The law was thus explicitly designed to remove fear of outstanding debt claimants as a motive for steering away from the use of electronic government transfers. Besides information about this law, the letter also listed the wider individual gains from receiving child benefits by direct deposit rather than by check. Reference is made to a number of other recent government measures that favour the usage of electronic welfare transfers.

This paper is thus related to a growing empirical literature on the role of information in various economic decisions. Hastings and Weinstein (2008) study the impacts of providing lower-income

\footnotetext{
${ }^{2}$ We shed light on the role of the packaging of information and task complexity on individuals' decision to switch payment method, and thus add power to the oft cited idea in the social psychology literature that many behavioural differences are influenced by small, easy to manipulate situational factors.

${ }^{3}$ This is 'the Law of June 14th 2004 regarding the protection against confiscation mentioned in Articles 1409, 1409bis and 1410 of the Legal Code when these sums are transferred electronically onto a bank account' as publicized in the "Belgian Bulletin of Acts, Orders and Decrees" on July 2nd 2004. A Royal Decree of July 4th 2006 that came into force on January 1st 2007 stipulated the practical arrangements necessary for the execution of the law.
} 
families with direct information about school-level academic performances on parents' school choice. Duflo and Saez (2003) investigate the effects of information on pension savings behaviour. Daponte, Sanders and Taylor (1999) investigate the role of information on participation in a food stamp program. Substantial empirical research has indeed also shown that imperfect information and program complexity effectively constitute important barriers to welfare benefit take-up (see e.g. Aizer, 2003; Aizer, 2007), and that such effects may in fact be more important than stigma (Currie, $2004){ }^{4}$

With the remaining four experimental manipulations, we essentially aimed to investigate whether simple "extra features" can augment the efficacy of the information campaign. The paper thus adds to a new direction for empirical research, which is to move beyond merely estimating the size of behavioural responses to information, and instead analyse how various specific nuances of presentation and framing can shape the size of the behavioural response (see e.g. Bertrand et al., 2008; Saez, 2008).

We designed two flyers that conveyed similar information as in the standard letter, but in a more transparent and easily accessible way. Furthermore, guided by a large body of cognitive literature about goal framing effects, we created one flyer that highlighted the gains from action (e.g., "Receiving your child benefit via direct transfers is much safer") and another that discussed the losses from inaction (e.g., "Receiving your child benefit via check is not safe"). Apart from the framing manipulation, the two flyers were identical. Our interest was to assess whether these flyers can effectively improve the responsiveness to the information provided, and whether the persuasive message had a different appeal depending on whether it stressed the positive consequences of switching or the negative consequences of not switching. Please find a copy of one of the flyers in the Appendix.

A common finding in the literature is that negative (loss) frames are more effective than positive (gain) frames in the context of goal framing, but this finding is far from robust. There is evidence of higher effectiveness for negative frames in the context of breast self-examination (Meyerowitz and Chaiken, 1987), evaluation of prizes or jobs (Tversky and Kahneman, 1991), and mammography screening (Banks et al., 1995; Rothman and Salovey, 1997). However, other studies have failed to find such effects in contexts such as breast self-examination (Lalor and Hailey, 1990), treatment of breast cancer (Siminoff, Fetting and Abeloff, 1989), testicular self-examination (Steffen et al., 1994), and follow-up for abnormal pap-smear test results (Lauver and Rubin, 1990). It has been suggested that the negative frame bias is linked to "loss aversion," that is, people's tendency to avoid a loss more than to achieve a gain of the same magnitude (e.g., Kahneman, Knetsch and Thaler, 1990; Tversky and Kahneman, 1991) or a "negativity bias in information processing," that is, people's tendency to be more responsive to negative information than objectively equivalent positive information (e.g. Fiske and Taylor, 1991).

\footnotetext{
${ }^{4}$ Theoretically, Kleven and Kopczuk (2005) also stress the importance of transaction costs and imperfect information for low participation in public programs. Likewise, Bertrand, Mullainathan and Shafir (2006) point to 'channel factors', 'mental accounts', commitment issues and default options as potential determinants of behaviour in addition to the classic economic assumptions. They argue e.g. that a key reason why the poor tend to steer away from bank accounts may be that they have little information about what may be some of the benefits of a bank account, but but do not present any evidence.
} 
The complexity of the decision to switch payment method may overwhelm beneficiaries, encouraging procrastination and reducing the response rate to the government-led information campaign (see e.g., Tversky and Shafir 1992, Shafir, Simonson and Tversky 1992, Dhar and Nowlis 1999, Iyengar and Lepper 2000 on the tendency of individuals to put off making decisions as the complexity of the task increases). Therefore, we designed an extra section to the flyer (and sent this to some treatment groups only) specifically aimed to simplify the complexity of the decision-making task at hand. This addition was essentially a specific, step-by-step plan to guide the beneficiary as to how (s)he can undertake the switch, which type of documents are needed, etc. And, anticipating that some recipients of this letter may not yet have an individual bank account, we also clarified how one should proceed to open up a bank account (prior to implementing the steps to switch payment method). Notably, we emphasized here that they are under no obligation at all to use a joint account with their partner, but free to open up and use their own individual account at a minimal cost of 12 Euros per year. This is an important element to highlight particularly since for some mothers, receiving child benefit support via check might be their way of securing control over how this money is spent.

We thus study the low-cost manipulation effects of simplifying the decision to switch payment method on beneficiaries' actual behaviour. Choi, Laibson and Madrian (2006) found that offering employees the Quick Enrollment ${ }^{T M}$ option, which likewise simplifies the decision to enroll in a 401(k) savings plan, significantly raised participation rates. Relatedly, Madrian and Shea (2001), Iyengar and Jiang (2003), and Iyengar et al. (2004) have argued that the complexity of the 401(k) savings decision discourages employees from timely enrollment, even when they prefer participation to non-participation. And Dynarski and Scott-Clayton (2006) have shown that the complexity of federal student aid application procedures disproportionately burdens those on the margin of college entry, thereby blunting the impact of aid on their schooling decisions. Gollwitzer and Brandstätter (1997) have demonstrated (experimentally) that people without a simple plan or firm implementation intentions are significantly less likely to attain their goal. Likewise, Leventhal, Singer and Jones (1965) found that when they provided subjects with specific plans for action versus general recommendations, this had a significant, positive effect on adherence to the recommended act (which was in their case, taking a tetanus shot). Thus, apart from the recent experimentation with the design 401(k) savings' enrollment forms, we are not aware of any other real-world, researchled experiments that have systematically looked at how simplifying a decision to act can indeed raise compliance behaviour.

\section{Setting, Experimental Design and Data}

We identify the effects of providing standard information, and of augmenting that standard information with goal framed information (presented in a flyer format) and implementation plans using randomly assigned variation in the direct mailings. The National Office for Family Benefits sent a mailing to 19,707 Clients, the full population of its beneficiaries paid by check (at the time of the information campaign), encouraging them to switch to electronic payment methods. The en- 
couragement was presented with variations on five randomly assigned information content features (as detailed in the previous section). Below, we describe the Belgian child support system and our cooperating Child Benefit Fund. We provide additional details about the experimental design. Finally, we introduce the data that we worked with.

\subsection{Child Benefit Support and the National Office for Family Benefits}

Our collaborator, the National Office for Family Benefits for Salaried Persons, is the sole governmental body in Belgium that administers child benefit support. With roughly 20 percent of 'market share', it is the largest of such agencies; the remaining 80 percent of child benefit support is served by 23 different private child benefit funds. ${ }^{5}$ Child benefit transfers in Belgium are essentially monthly, lump-sum government payments, which vary with the number, rank and age of children in the household and are augmented with means-tested supplementary allowances. ${ }^{6}$ Typically, child benefit support constitutes a very significant source of household income; to illustrate, for a household with a median income and two children between the ages of 12 and 17, child benefit transfers represent over 25 percent of that household's net income. Hence, any systematic relationship between payment mode and household spending and saving decisions (see e.g. Berg, 2007) is likely to be consequential to household welfare. This makes it very important to understand how payment method decisions are made, and how they can be influenced.

At the time of the information campaign, nearly 10 percent of the National Office for Family Benefits' Clients were paid by check. It is noteworthy that child benefit checks were (and still are) in practice $^{7}$ the 'default option,' that is to say, if the beneficiary does nothing, the default is that the beneficiary will receive the child benefit payment by check. Moreover, the standard procedure to set up payment via direct transfer is complex, requiring e.g. signatures from both the beneficiary and his/her bank. ${ }^{8}$ There is substantial evidence on the sizeable effects that defaults can have on economic decisions and outcomes, particulary when the decision-making task at hand is complex (see e.g. Beshears et al., 2006).

Finally, a brief note on terminology. The National Office for Family Benefits essentially distin-

\footnotetext{
${ }^{5}$ Clients of the National Office for Family Benefits appear to be representative of the Belgian population as a whole. Along none of the basic socio-demographic dimensions, we find any systematic deviations from the population of Belgian households with children.

${ }^{6}$ At the time of our study, the basic monthly benefits for the first, the second and the third child were 81.77 , 151.30 and 225.90 euros, respectively. These basic amounts are augmented by an age supplement, which at the time of our study, equalled 28.41 euros (for a child between 6-11 years old), 43.41 euros (for a child between 12-17 years old) or 55.19 euros (for a child between 18-24 years old). The social supplement varied between 20.81 and 41.63 euros.

${ }^{7}$ Until recently, the Law on Child Benefits (article 68) specified child benefit payment by check as the default option. In early 2007 this has been changed to electronic payment. In practice, however, payment by check remains the 'default' option in the sense that this payment method does not require any action from the beneficiary, while receiving child benefits electronically does.

${ }^{8}$ In order to receive a direct transfer, an official document needs to be completed and sent back to the National Office of Family Benefits. The upper part of this document has to be filled in by the beneficiary, who has to give his or her name, address, social security number, date of birth and bank account number, whereas the lower part of the document must be filled in by the bank. The latter has to confirm that the beneficiary can dispose independently of the money trasnferred onto the bank account.
} 
guishes three types of 'entitled individuals' ${ }^{9}$ based on the latter's status in the labour market. The first group comprises employees, i.e., those individuals who activated their entitlement through their status as employee or former employee (say in case of unemployment, pension, decease or disability), with the exception of those employed or formerly employed in the public sector. There is a second, separate group comprised of civil servants only, i.e., individuals who activated their entitlement through their employment or former employment at a government institution. Finally, the third group consists of individuals who currently do not or have never actively participated in the labour market and thus are unable to claim a right to child benefit support on the basis of their active labour market position. The overwhelming majority of entitled individuals that belong to this third group (90 percent to be precise) receive basic income support, which indicates that this group comprises a disproportionate share of needy households. These individuals are entitled to so-called guaranteed child benefits ${ }^{10}$. The guaranteed child benefits are fully administered by the National Office for Family Benefits and not by private child benefit funds. Finally, it is noteworthy that the 'entitled individual' is not necessarily the beneficiary who actually receives the child benefit: for over half of all individual child benefits granted, the entitled individual is the father, whereas the beneficiary is typically the mother. ${ }^{11}$

\subsection{Experimental Design}

Using the administrative data from the National Office for Family Benefits, we selected the entire population of Clients who at the time of the mailing (in April 2007) received their child benefit support via check $(N=19,707)$. This group was then stratified (or blocked) using the following set of beneficiary-specific control variables: age, sex, total number of children for which the individual receives child benefit support, recipient of a social supplement ${ }^{12}$ (binary variable), language (Dutch or French), status type of the entitled individual linked to the beneficiary, region of residence (Flanders, Wallonia, Brussels Capital), province of residence, and degree of urbanisation of area of residence. ${ }^{13}$ Afterwards, we randomly assigned Clients in each stratum to one of the following six groups:

\footnotetext{
${ }^{9}$ In the Belgian system of child benefits the entitled opens the right to family benefits through his or her labour as a salaried or self-employed person or civil servant. To determine the entitled the following hierarchy is adopted: (1) if the child is an orphan, he or she will be the entitled, (2) the person taking care of the child's upbringing has a priority of he or she who does not, (3) father $>$ mother $>$ stepfather $>$ stepmother $>$ eldest entitled, and (4) in case of joint parental authority, a father outside the family has always priority over a mother within the family.

${ }^{10}$ The term 'guaranteed' simply underscores the fact that according to Belgian law, with every child residing in Belgium there is a right to child benefit. In other words, the third group is the residual of groups one and two.

${ }^{11}$ If it is not the mother, it is the person or institution who is responsible for the child's upbringing. In a small number of cases, the beneficiary is the qualifying child him- or herself, namely if he or she is married, if he or she is emancipated, if he or she is 16 years or older and not living with the person by whom he or she was actually raised, or if he or she is beneficiary for one or more children him- or herself.

${ }^{12}$ Those entitled to a retirement pension, fully entitled unemployed from their seventh month of joblessness onwards and disabled employees from their seventh month of disablement, who are entitled to family benefits, receive a social supplement. Under certain conditions, these persons retain their rights to the social supplement when they start an activity as a salaried worker. This supplement depends on the child's rank in the family. For the disabled employee the supplement is higher than for other categories.

${ }^{13}$ We thus ensured that our treatment and control groups were similar along those important observable dimensions, which were likely to explain the treatment effect.
} 
1. Standard information letter only,

2. Standard information letter plus positively framed flyer,

3. Standard information letter plus negatively framed flyer,

4. Standard information letter plus positively framed flyer plus specific plan,

5. Standard information letter plus negatively framed flyer plus specific plan, and

6. Control group, who received the standard, information letter with a two months delay in June 2007.

At the time of our 'sample' selection, the National Office of Family Benefits served only 190 German speaking beneficiaries, 60 of them being paid by check (that is, 0.3 percent of 19,707). This group was in block assigned to treatment group receiving only the standard information letter, because the National Office of Family Benefits judged that the costs of translating the flyers and specific plan would have been proportionately too high and because the number of German speaking beneficiaries per stratum would have become negligeably small. Because they were not assigned randomly to the treatment groups, the 60 German speaking beneficiaries were not included in the final analyses.

Further, we conducted our analysis on a sample that slightly deviated from the original sample for several additional, notably tractable and justifiable, reasons. First, we dropped those Clients that had left the National Office for Family Benefits by June (1,279 cases). Luckily, this attrition was non-voluntarily, rather for reasons such as a change of employer or because the age of the child exceeded the maximum age for entitlement to family benefits. Furthermore, we found that Clients who had dropped out of our sample were equally spread across the treatment groups, suggesting that our initial randomisation was indeed successful. Second, we excluded from our analyses those individuals who had not yet received two child benefit payments at the time of the experiment (145 cases). We isolated this group using detailed data on each beneficiary's payment history since February 2006. The idea here was to exclude beneficiaries who were perhaps still paid via check simply because they had not yet had the chance to inform the National Office of their bank account details. Furthermore, we also excluded the 119 beneficiaries who were beneficiary for children from more than one entitled individual. Many of these beneficiaries had mistakenly received two different mailings, because in the original dataset they were included twice or more (once for every entitled individual they were associated with). Finally, 98 cases were left out of the analysis because they had a missing variable on one of our predictor variables, namely marital status. Importantly, on none of our beneficiary-specific variables/dimensions did the resulting sample of 18,006 individuals statistically differ from the original sample of 19,707 individuals. Furthermore, the attrition was equally spread over the different treatment groups. The final size of the treatment groups was on average 3,001 , with a minimum of 2,951 and a maximum of 3,039 .

Using a large-scale randomized field experiment to estimate the impacts of information on payment method choice straightforwardly presents several unique advantages relative to say using laboratory 
evidence or evidence from a natural field experiment. ${ }^{14}$ At the same time, ethical and practical concerns raised by the National Office for Family Benefits also put some constraints on our experimental design. First, because the National Office for Family Benefits is a governmental body it is obliged to guarantee equality of treatment and information to all its beneficiaries. Therefore, it was ethically unfeasible to delay the mailing to individuals in the control group by more than two months. However, we judged that this constraint was unlikely to limit the scope or reliability of our research: we expected that the biggest impact of our treatments would occur during the first two months after the mailing. Moreover, after two months, it would become increasingly difficult to separate out the mailing effect from potential other confounding effects such as social network effects (e.g., via conversations of the beneficiaries with family or friends who had also received a (maybe different) mailing). Second, the standard information letter had to be sent to all of the beneficiaries. We were thus able to study the incremental effect of the flyer and the specific plan, but not the net effects. A significant incremental effect can be the result of two mechanisms (or a combination of both), namely the effect of the supplement itself, and the effect of a repetition of the message.

\subsection{Data}

We gathered detailed information on each Client making use of three different data sources: the administrative database of the National Office for Family Benefits for Salaried Persons, the National Registry, and the Crossroads Bank for Social Security. ${ }^{15}$ To merge the data from these sources, we used the beneficiaries' unique national identification number, made available to us (anonymously) by the Crossroads Bank.

In order to assess the effects of the experiment on choice of payment method, the National Office for Family Benefits provided us with three waves of data: April 2007 (on the date of the mailing), June 2007 (two months after the mailing) and finally October 2007 (6 months after the mailing). The data included information on the payment method, as well as on several beneficiary related characteristics: the beneficiary's sex, age group, labour market status, nationality, region and province of residence, whether the individual received a social supplement, and the number of children for which the beneficiary received child support. To obtain an indicator of the degree of urbanization of the beneficiary's residence, we made use of the classification developed by Van Hecke and his colleagues (Van Hecke, 1998; Van Hecke and Luyten, 2007), which links zipcodes (here, of where the beneficiary lives) to one of eight distinct urbanization types. ${ }^{16}$

\footnotetext{
${ }^{14}$ They allow us to observe people's behaviour in a 'natural' setting. Harrisson and List (2004) put it as follows: 'What passes for "control" in laboratory experiments might in fact be precisely the opposite if its is artificial to the subject or context of the task. (...) Dissecting the characteristics of field experiments helps define what might be better called an ideal experiment, in the sense that one is able to observe a subject in a controlled setting but where the subject does not perceive any of the controls as being unnatural and there is no deception being practiced'.

${ }^{15}$ The Crossroads Bank for Social Security brings together detailed data on all social security sectors in Belgium. Access to these data was approved by the Belgian Privacy Commission.

${ }^{16}$ Unfortunately, the Belgian law on privacy prevented us from accessing the actual zipcode data. We are therefore unable to investigate the potential effects of social networks on people's decision to switch to electronic welfare payments.
} 
We gathered details on the beneficiary's marital status using the National Registry. However, since marital status only refers to the status of the beneficiary as registered officially, we complemented this measure with another categorical variable indicating whether the entitled individual and beneficiary are part of the same household (cohabitation). To do so, we took advantage of the fact that the National Registry includes a unique household identifier. This newly constructed variable comprises four categories: beneficiary and entitled live in the same household, beneficiary and entitled live in different household, beneficiary and entitled are the same individual, and a rest group with unknowns. We also used the National Registry to collect information about the nationality of each beneficiary. Finally, we established whether the beneficiary was (at the time of our sample selection) employed as a salaried person (employed) using data from the Crossroads Bank.

The summary statistics for the sample of 18,006 Clients paid by check (at the time of the experiment) are displayed in Table 1, broken down into six groups. Panels A, B and C present, respectively, beneficiary-specific background characteristics, child benefit-related characteristics, and residence-related characteristics. Evidently, the overwhelming majority of beneficiaries were female. Nearly two-thirds of beneficiaries were aged between 25 and 44, and approximately half of the beneficiaries were married. Most of the beneficiaries (83,6 \%) had the Belgian nationality. Also, the largest share of entitled individuals had been unemployed for over six months, and around 60 percent of beneficiaries received child benefit support for one child only. Finally, over half of beneficiaries lived in Wallonia. Because the groups were stratified and were chosen randomly, the mean of observable beneficiary-specific characteristics such as sex, age and marital status, and regional-specific characteristics such as region and degree of urbanization, are very similar across groups, and none of the differences are significant.

\section{Results}

\section{A. The Large Behavioural Responses To The Information Campaign}

In Panel D of Table 1, we can see that overall the mailings produced a large, behavioural response; indeed, in the treated groups, as many as 25 percent of Clients switched, whereas in the control group, fewer than 4 percent switched. In other words, treated beneficiaries were more than four times as likely to switch payment method than control beneficiaries. Notably one out of four treated beneficiaries effectuated a change in payment mode during the two months following the information campaign.

Furthermore, additional evidence suggests that effectively without the information campaign, the new Law of January 2007 did not significantly impact parents' payment method choices. Figure 1 simply plots the evolution of the proportion of National Office Clients paid by check over time between February 2006 and December 2007. We can observe a steadily declining trend in the proportion of Clients paid by check, and an apparent discontinuity around May/June 2007. Further, in Table 2, we present the estimation results of different linear regression models designed to 
predict this evolution. The first column ('No step function') shows that a simple linear regression model with the percentage beneficiaries as a function of time (i.e. the number of months included as a continuous predictor) already fits the data well $\left(R^{2}=0.880\right)$. The parameter estimate for time is, as already suggested by Figure 1, negative and significant. In the three other columns, we fit subsequent step functions -i.e., while the overall slope of the function remains constant over time, we allow the function to make a move up or down at specific moments in time. In other words, we include new dummy variables that have a value of zero in all the time intervals before, and a value of one in all the time intervals after a certain moment. The second column on the left ('Step function: March 2007') shows that allowing the function to move up or down in March 2007, two months after the enactment of the Law, does not produce a substantial improvement in the fit of the model. Indeed, the parameter estimate associated with the March 2007 dummy is not statistically significant. Including a June 2007 dummy (thus allowing the function to move up or down two months after the mailing), by contrast, does improve the fit significantly $\left(R^{2}=0.991\right)$. The parameter estimate associated with the dummy is negative and highly significant. Finally, including two dummies, one for June 2007 (two months after the first mailing) and one for August 2007 (two months after the mailing to the control group) produces an even better fit $\left(R^{2}=0.996\right)$. The parameter estimates for both dummies are negative and highly significant -with notably the former coefficient estimate being larger than the latter, which is exactly what we would expect because the second mailing was sent to a much smaller group of beneficiaries. Figure 2 graphically illustrates these findings. The step function with a dummy variables for June 2007 and August 2007, respectively, yields predicted values that coincide almost perfectly with the observed values.

Of course, the analyses presented in Table 2 and Figure 2 do not straightforwardly establish a causal relationship between providing information and payment method choice, since other factors or events might be at play. Nevertheless, we can readily exclude the following set of competing explanations for the discontinuities found around June 2007 and August 2007. That is, we do not observe a statistically significant change in the demographic profile of Clients of the National Office for Family Benefits' over the 23-month period under scrutiny. ${ }^{17}$ Also, we do not observe any new regulation, change in child benefit eligibility criteria or change in the price of cashing checks coinciding with the timing of the information campaign and which might have produced a similar effect on parents' payment method choice. To summarize, the evidence presented so far indicates that the new Law alone did not effectuate any significant change in electronic payment usage, whereas the information campaign by contrast produced a large and significant effect.

Finally, the evidence on the responsiveness to the standard letter by those who were initially in the control group allows us to perform a consistency check. Importantly, we cannot reject the hypothesis that by October 2007 the compliance rates for those treated (standard letter only) in April and those treated (standard letter only) in June were statistically the same.

\section{B. Simple Supplements Can Amplify The Effects of Information}

\footnotetext{
${ }^{17}$ We established this by comparing the summary statistics on Client characteristics, which are presented in the National Office for Family Benefits' quarterly reports.
} 
A simple comparison of mean switching rate between the standard letter and standard letter plus flyer groups (column (1) versus columns (2) and (3) in Panel D of Table 1) readily shows that adding the flyers raised the switching rate by just over two percentage points relative to the standard information alone. Further, the difference in mean switching rate between the standard letter plus flyer groups and standard letter plus flyer plus specific plan groups (columns (2) and (3) versus (4) and (5) in Panel D of Table 1) amounts to roughly another two percentage points. Both flyer and flyer plus implementation plan thus appear to have noticeably improved the effectiveness of the standard letter alone.

To further analyse the size of the (compliance) effects across treatment groups, we considered a simple reduced-form regression specification. Let $y_{i j}$ denote whether beneficiary $i$ in group $j$ changed payment method from payment by check to payment via direct transfer. $D_{i j}$ is the dummy for receiving treatment $j$ with $j=2, \ldots, 6$, corresponding with each of the five treatments. The average effects on switching of being in one of the five alternatively treated groups rather than in the control group is then captured by the following specification:

$$
y_{i j}=\alpha_{1}+\beta_{2} D_{i 2}+\beta_{3} D_{i 3}+\beta_{4} D_{i 4}+\beta_{5} D_{i 5}+\beta_{6} D_{i 6}+\gamma \cdot X_{i j}+\varepsilon_{i j}
$$

where $X_{i j}$ is a set of beneficiary-specific control variables. $X_{i j}$ includes all stratification variables, and additional background variables such as marital status or whether the beneficiary receives a social supplement. The estimates of $\beta_{2}, \beta_{3}, \beta_{4}, \beta_{5}$ and $\beta_{6}$ are the parameters of primary interest; they correspond, respectively, to the difference in switching rate between the five treatment groups on the one hand, and the control group, on the other. $\varepsilon_{i j}$ is the standard, robust beneficiary-level error term.

Table 3 summarizes the regression results. We readily see that each of the five treatments significantly raised compliance relative to the control group, controlling for the stratification variables and other beneficiary-specific characteristics. More specifically, being in the positively framed or negatively framed flyer treatment groups raised the average switching rate by over 2 percentage points relative to the standard letter group. Furthermore, being in the positively framed or negatively framed flyer plus specific plan treatment groups increased the average switching rate by respectively over 4 percentage points, again relative to the standard letter group. These estimates correspond to the difference in average switching rate reported in Panel D of Table 1. Obtaining significant differences between the four supplement treatment groups, respectively, and the standard letter group signify that the (goal framed) flyers and (goal framed) flyers plus specific plan did have an impact on switching. This impact is large in relative terms (raising the likelihood of switching by 10 to 18 percent after 2 months), though perhaps small in absolute terms (an increase of 2 to 4 percentage points on a base of 24 percent).

Our experiment does not allow us to unambiguously distinguish between the following interpretations for the estimated $\beta_{3}, \beta_{4}, \beta_{5}$ and $\beta_{6}$. The significant incremental effects of adding the flyer to the standard letter on people's payment method choice might have been the result of the specific information presentation format, where information was graphically portrayed, in a familiar, easyto-comprehend format (see e.g. Winett and Kagel, 1984) or the consequence of the repetition of 
the self-relevant information (see e.g. Claypool et al., 2004; Capioppo and Petty, 1989). Likewise the further rise in individuals' responsiveness when sent both the supplementary flyer and supplementary implementation plan is consistent both with the impacts of repetition, but also with the impacts of having a simple plan or firm implementation intentions (see e.g. Ajzen, 1985 and 1991).

Further, the results summarized in Table 3 also indicate that the likelihood of switching payment method was significantly lower amongst younger parents relative to the group of 35 through 44 of age. One explanation for this is that younger households tend to be in a financially more precarious situation, lowering the perceived returns from bank account ownership. Also, parents who had been paid by check for a longer time were significantly less likely to switch, thus exhibiting greater vulnerability to the status quo bias (see e.g., Samuelson and Zeckhauser, 1988). Parents with a social supplement or a guaranteed child benefit displayed a significantly higher likelihood of switching payment method. One interpretation of the latter finding is that these people typically receive greater support from community welfare workers, who might not only provide assistance with the switching decision but also actively promote this decision. The results also show that none of the residence-related characteristics were significant predictors of the beneficiary's likelihood of switching payment method.

Interestingly, foreigners were not only more likely to switch to electronic payment methods, they were also significantly more responsive to the information campaign compared to Belgians. Relatedly, though in the context of US medicare, Aizer (2003) found that the positive effect of an outreach campaign on Medicaid enrollments was significantly higher for Hispanics and Asians. We provide two interpretations to account for our result. First, since foreigners typically face higher complexity and informational costs due to language and immigration concerns, they are likely to benefit more from any information campaign. Alternatively, given that child benefit support typically constitutes a larger share of foreigners' income, any welfare gains from switching payment method (e.g. savings) are likely to be more consequential for this group and therefore new information about these gains is more likely to trigger a behavioural response.

Finally, our results do not show any valence or goal framing effects, neither when we compare compliance across the two flyer only groups, nor when we compare compliance across the flyer plus specific plan groups. Specifically, the mean switching rate in group 2 and group 3 is not significantly different. Likewise, we cannot reject the hypothesis that the mean switching rates in group 4 and group 5 are equal. One plausible explanation for why we find no goal framing effects is that the topic of our message had high intrinsic self-relevance to the beneficiaries. High intrinsic self-relevance is instantiated when a decision maker spontaneously relates to the decision context. This was by construction the case since all beneficiaries we knew were receiving their child benefit via check. Extending the framework by Levin, Schneider, and Gaeth (1998) to explain previously observed discrepancies in the effects of positive versus negative framing, Krishnamurthy, Carter and Blair (2001) indeed suggest that valence effects may not occur in the context of goal framing when the research topic has high intrinsic self-relevance to the research population.

\section{Implementation Plans Favour Early Versus Late Response}


To conclude, we examine to what extent the supplement treatments impacted the speed by which parents decided to switch payment method. Extensive literature has indicated that the inability to formulate a plan can block behaviours altogether (see e.g. Lewin, 1951). Leventhal, Singer, and Jones (1965) found that providing a map of the campus and urging students to make a plan on how and when to go to the infirmary can significantly improved the effectiveness of a message to get a tetanus shot. Owens, Bowman and Dill (2008) relatedly argue that implementation plans can help overcome procrastination. To test this prediction empirically, we run the following basic Probit regression for each beneficiary who was sent a mailing in April 2007 and switched payment method during the subsequent six months:

$$
\operatorname{Pr} o b\left(e_{i j}=1\right)=\alpha_{1}+\beta_{2} D_{i 2}+\beta_{3} D_{i 3}+\beta_{4} D_{i 4}+\beta_{5} D_{i 5}+\gamma \cdot X_{i j}+\varepsilon_{i j}
$$

where $e_{i j}$ is a dummy variable for whether the beneficiary switched early, and as before $X_{i j}$ is a set of beneficiary-specific control variables. $X_{i j}$ includes all stratification variables, and additional background variables such as marital status or whether the beneficiary receives a social supplement. The estimates of $\beta_{4}$ and $\beta_{5}$ are the parameters of special interest; they correspond, respectively, to the difference in switching early (versus late) between the two flyer plus implementation plan treatment groups, respectively, and the standard letter group. $\varepsilon_{i j}$ is the standard, robust beneficiary-level error term.

Table 3 summarizes the results. We find that the flyer plus specific plan treatments significantly raised the propensity to switch to automatic transfers early (rather late) relative to the standard letter only. Adding a flyer alone achieved no such effects. These findings suggest that providing implementation plans can effectively counteract people's tendency to procrastinate.

\section{Conclusion}

Our findings suggest that information matters for important economic decisions. We find that a one-time mailing providing information about method of payment for child benefit support caused a fourfold increase in parents' decision to switch to electronic benefit transfers. The magnitude of the behavioural response to the mailings were the highest amongst foreigners. Supplements to the standard letter effectively raised people's responsiveness to mailing: adding a simple flyer alone or flyer and implementation plan augmented the compliance with the mailing's message by, respectively, 2 and 4 percentage points. Overall, our results support the view that complexity and information (processing) costs pose significant barriers to transitioning to electronic payment methods, and that deliberate efforts to lower these costs can contribute to large behavioural changes.

The increase in administrative saving generated by the mailing was much greater than its costs. The mailing induced 4,114 beneficiaries to change payment method during the first two months after the experiment. The administrative saving due to the early switches in response generated by the mailing was thus about 5,143 euros per month or over 61,710 on a yearly basis. The overall costs of the experiment amounted to 9,494 euros. Therefore, the net saving obtained is no doubt 
large relative to the encouragement costs. ${ }^{18}$ Our experiment thus neatly illustrates that the use of marketing techniques need not be in conflict with (severely) limited government budgets.

Understanding the impediments to electronic payment method usage is important for at least two more reasons besides the administrative cost saving argument. First, banking at the financial fringes (e.g. using check cashing agencies) typically implies incurring much higher fees. Switching to electronic government transfers could be a first step towards becoming part of the typically less exploitative mainstream. Second, the direct deposit of payments can be instrumental to increasing savings and spending in more socially desirable ways. We have shown that a lack of information and task complexity can form decisive obstacles to electronic payment method usage. We thus point to the role of 'channel factors' as important determinants of consumers' method of payment choice that have arguably been overlooked in that literature. At the same time, in light of the still substantial rate of non-responses to the campaign, to argue that payment by check should therefore become mandatory is simply premature; rather, our results lend support to measures like changing the default from payment by check to electronic payment.

In our experiments, we varied the content of the mailing exogenously in order to begin to understand the relationship between informational content, format and frames and people's choice of method of payment. The incremental effects on individuals' method of payment choice generated by the flyer and flyer plus specific plan were notably small, but non-trivial. Overall, the fact that the one-time mailings achieved such large behavioural effects suggests that the processes of information acquisition may be more complex and more consequential than economists have traditionally imagined.

\section{$6 \quad$ List of references}

\section{References}

[1] Aizer, A. (2003), "Low take-up in medicaid: does outreach matter and for whom?" American Economic Review Papers and Proceedings, 93 (2): 238-241.

[2] Aizer, A. (2007), "Public health insurance, program take-up, and child health," Review of Economics and Statistics, 89(3): 400-415.

[3] Ajzen, I. (1985), "From intentions to actions: A theory of planned behavior," In J. Kuhl \& J. Beckman (Eds.), Action control: From cognition to behavior, Berlin, Germany: SpringerVerlag.

[4] Ajzen, I. (1991), "The theory of planned behavior," Organizational and Human Decision Processes, 50: 179-211.

\footnotetext{
${ }^{18}$ Given the very low marginal cost of adding the flyer and specific plan to the standard letter, the cost-benefit ratios for these supplements alone indicate even much higher returns to the associated outlay. One euro spent on adding the flyer yielded a three euro savings; one euro spent on adding the specific plan, yielded a 26 euro savings.
} 
[5] Banks, S.M., P. Salovey, S. Greener, A.J. Rothman, A.J., A. Moyer, J. Beauvais, and E. Eppel (1995), "The effects of message framing on mammography utilization," Health Psychology, 14 (2): $178-184$.

[6] Berg, E. (2007), "Does payment into bank accounts encourage saving? Evidence from South Africa", LSE Working paper, available from http://personal.lse.ac.uk/berge/savings.pdf.

[7] Bertrand M., S. Mullainathan and E. Shafir (2006), "Behavioral economics and marketing in aid of decision making among the poor," Journal of Public Policy and Marketing, 25 (1), 8-23.

[8] Bertrand, M., D. Karlan, S. Mullainathan, E. Shafir and J. Zinman (2008), "What's Advertising Content Worth? Evidence from a Consumer Credit Marketing Field Experiment," Working Paper.

[9] Beshears, J.J., J. Choi, D.I. Laibson \& B.C. Madrian (2006), "The Importance of Default Options for Retirement Savings Outcomes: Evidence from the United States," NBER Working Paper, No. W12009.

[10] Cacioppo, J.T. and R.E. Petty (1989), "Effects of message repetition on arguent processing, recall and persuasion," Basic and Applied Social Psychology, 10: 3-12.

[11] Choi, J., D. Laibson and B.C. Madrian (2006), "Saving for retirement on the path of least resistance," in Behavioral Public Finance: Toward a New Agenda, edited by E. McCaffrey and J. Slemrod, New York: Russell Sage Foundation, 304-351.

[12] Claypool, H.M., D.M. Mackie, T. Garcia-Marques, A. McIntosh and A. Udall (2004), "The effects of personal relevance and repetition on persuasive processing," Social Cognition, 22(3), 310-335.

[13] Currie, J (2004), "The take-up of social benefits," NBER Working papers 10488.

[14] Daponte, B.O., S. Sanders and L. Taylor (1999), "Why do low-income households not use food stamps? Evidence from an experiment," Journal of Human Resources, 34 (3), 612-628.

[15] Dhar, R. and S.N. Nowlis (1999), "The effect of time pressure on consumer choice deferral," Journal of Consumer Research, 25 (4), 369-384.

[16] Duflo, E. and E. Saez (2003), "The role of information and social interactions in retirement plan decisions: Evidence from a randomized experiment," Quarterly Journal of Economics, $188(3), 815-842$.

[17] Dynarski, S.M. and J.E. Scott-Clayton (2006), "The Cost of Complexity in Federal Student Aid: Lessons from Optimal Tax Theory and Behavioral Economics," NBER Working Papers 12227.

[18] Fiske, S.T. and S.E. Taylor (1991), Social cognition. New York: McGraw Hill.

[19] Gollwitzer, P.M and V. Brandstätter (1997), "Implementation intentions and effective goals pursuit," Journal of Personality and Social Psychology, 73, 186-199. 
[20] Harrison, G.W. and J.A. List (2004), "Field experiments," Journal of Economic Literature, XLII, 1009-1055.

[21] Hastings, J.S. and J.M. Weinstein (2008), "Information, school choice and academic achievement: evidence from two experiments," Quarterly Journal of Economics, Forthcoming.

[22] Iyengar, S.S. and W. Jiang (2003), "Choosing not to choose: the effect of more choices on retirement savings decisions," Columbia University, Working Paper.

[23] Iyengar, S.S., W. Jiang and G. Huberman (2004), "How much choice is too much? Contributions to 401(k) retirement plans," in Pension Design and Structure: New lessons from behavioral finance, edited by O. Mitchell and S.Utkus, Oxford, UK: Oxford University Press, 83-96.

[24] Iyengar, S. S., \& M.R. Lepper (2000), "When choice is demotivating: Can one desire too much of a good thing?," Journal of Personality and Social Psychology, 79: 995-1006.

[25] Kahneman, D., J. Knetsch and R. Thaler (1990), "Experimental tests of the endowment effect and the coase theorem," Journal of Political Economy, 98: 1325-1348.

[26] Kleven, H.J. and W. Kopczuk (2005), "Welfare program complexity and the take up of social benefits," Working Paper.

[27] Krishnamurthy P., P. Carter P. and E. Blair (2001), "Attribute framing and goal framing effects in health decisions," Organizational Behavior and Human Decision Processes, 85 (2): $382-399$.

[28] Lalor, K.M. and B.J. Hailey (1990), "The effects of message framing and feelings of susceptibility to breast cancer on reported frequency of breast self-examination," International Quarterly of Community Health Education, 10: 183-192.

[29] Lauver, D. and M. Rubin (1990), "Message framing, dispositional optimism and follow-up for abnormal Papnicolaou tests," Research in Nursing and Health, 13: 199-207.

[30] Leventhal, H., R. Singer and S. Jones (1965), "Effects of fear and specificity of recommendation upon attitudes and behavior," Journal of Personality and Social Psychology, 2, 20-29.

[31] Levin, I.P., S.L. Schneider and G.J. Geath (1998), "All Frames Are Not Created Equal: A Typology and Critical Analysis of Framing Effects," Organizational behaviour and human decision processes, 76 (2): 149-188.

[32] Lewin, K. (1951), "Field theory and learning", in D. Cartwright (ed.), Field theory in social science (pp 60-86), New York: Harper \& Row.

[33] Madrian, B.C. and D.F. Shea (2001), "The power of suggestion: inertia in 401(k) participation and savings behavior," Quarterly Journal of Economics, 116(4): 1149-1187. 
[34] Meyerowitz, B.E. and S. Chaiken (1987), "The effect of message framing on breast selfexamination attitudes, intentions and behavior," Journal of Personality and Social Psychology, 52: $500-510$.

[35] Owens, S.G., C.G. Bowman and C.A. Dill (2008), "Overcoming procrastination: the effect of implementation intentions," Journal of Applied Social Psychology, 38(2): 366-384.

[36] Rothman, A.J. and P. Salovey (1997), "Shaping perceptions to motivate healthy behavior: The role of message framing," Psychological Bulletin, 121: 3-19.

[37] Saez, E. (2008), "Details Matter: The Impact of Presentation and Information on the Takeup of Financial Incentives for Retirement Saving," American Economic Journal: Economic Policy, Forthcoming.

[38] Samuelson, W. and R. Zeckhauser (1988), "Status quo bias in decision making," Journal of Risk and Uncertainty,1 (1): 7-59.

[39] Siminoff, L.A., J.H. Fetting and M.D. Abeloff (1989), "Doctor-patient communication about breast cancer adjuvant therapy," Journal of Clinical Oncology, 7(9): 1192-12

[40] Simonson, I., and Tversky, A. (1992): "Choice in context: Tradeoff contrast and extremeness aversion," Journal of Marketing Research , 29(3): 281-295.

[41] Steffen, V. J., L. Sternberg, L.A. Teegarden and K. Shepherd (1994), "Practice and persuasive frame: Effects on beliefs, intention, and performance of a cancer self-examination," Journal of Applied Social Psychology, 24: 897-925.

[42] Thaler, R.H. (1990), "Saving, fungibility and mental accounts," Journal of Economic Perspectives, 4: 193-205.

[43] Thaler, R.H. (1999), "Mental accounting matters," Journal of Behavioral Decision Making, 12(3): 183-206.

[44] Tversky, A. and D. Kahneman (1991), "Loss Aversion in Riskless Choice: A ReferenceDependent Model," Quarterly Journal of Economics, 106(4): 1039-61.

[45] Tversky, A. and E. Shafir (1992), "Choice under conflict: the dynamics of deferred decision," Psychological Science, 3(6): 358-361.

[46] Van Hecke, E. and S. Luyten (2007), "Verstedelijking, Monografie van de SE Enquête 2001," Algemene Directie Statistiek en Economische Informatie.

[47] Van Hecke, E. (1998), "Actualisering van de stedelijke hiërarchie in België," Tijdschrift van het Gemeentekrediet, 205.

[48] Winett, R.A. and J.H. Kagel (1984), "The effects of information presentation format on resource use in field stueies," Journal of Consumer Research, 11(2): 655-667. 
TABLE 1

COMPARISON OF THE TREATMENT GROUPS

\begin{tabular}{|c|c|c|c|c|c|c|}
\hline & Standard Letter & + Framed Flyer & - Framed Flyer & $\frac{+ \text { +Framed Flyer } \&}{\underline{\text { Plan }}}$ & $\frac{\text { - Framed Flyer \& }}{\underline{\text { Plan }}}$ & $\underline{\underline{\text { Control }}}$ \\
\hline & $(1)$ & $(2)$ & (3) & (4) & (5) & (6) \\
\hline & \multicolumn{6}{|c|}{ PANEL A: BENEFICIARY-SPECIFIC BACKGROUND CHARACTERISTICS } \\
\hline SEX & & & & & & \\
\hline$\%$ females & 91.92 & 91.87 & 92.22 & 91.58 & 91.87 & 91.45 \\
\hline \multicolumn{7}{|l|}{ AGE } \\
\hline$\%$ of individuals $<18$ years old & 0.43 & 0.59 & 0.33 & 0.4 & 0.58 & 0.5 \\
\hline$\%$ of individuals aged $18-20$ & 3.24 & 3.62 & 3.33 & 3.23 & 3.19 & 3.31 \\
\hline$\%$ of individuals aged $21-24$ & 7.81 & 7.86 & 7.98 & 8.01 & 7.73 & 8.12 \\
\hline$\%$ of individuals aged $25-34$ & 30.22 & 30.47 & 30.05 & 30.27 & 30.53 & 30.27 \\
\hline$\%$ of individuals aged $35-44$ & 32.32 & 32.31 & 33.28 & 33.37 & 32.63 & 32.06 \\
\hline$\%$ of individuals aged $45-54$ & 19.33 & 18.92 & 18.73 & 18.38 & 19.32 & 19.28 \\
\hline$\%$ of individuals aged $55-64$ & 3.91 & 3.92 & 3.96 & 3.87 & 3.76 & 4.21 \\
\hline$\%$ of individuals aged $>64$ & 2.74 & 2.3 & 2.34 & 2.46 & 2.27 & 2.25 \\
\hline \multicolumn{7}{|l|}{ NATIONALITY } \\
\hline$\%$ Belgian nationality & 77.33 & 78.64 & 77.54 & 78.55 & 77.43 & 77.54 \\
\hline \% EU 15 nationality & 0.9 & 0.46 & 0.4 & 0.57 & 0.68 & 0.6 \\
\hline$\%$ EU 12 nationality & 8.21 & 6.52 & 8.21 & 7.24 & 8.2 & 7.32 \\
\hline$\%$ Northwest African nationality & 1.87 & 2.04 & 1.95 & 2.36 & 1.63 & 2.55 \\
\hline$\%$ Other nationality & 11.69 & 12.34 & 11.91 & 11.28 & 12.06 & 11.99 \\
\hline \multicolumn{7}{|l|}{ MARITAL STATUS } \\
\hline$\%$ unmarried individuals & 31.62 & 31.52 & 31.33 & 30.67 & 32.36 & 31,67 \\
\hline$\%$ married individuals & 49.08 & 48.6 & 48.55 & 48.01 & 48,12 & 48.53 \\
\hline \% widows / widowers & 3.71 & 3.42 & 3.17 & 3.57 & 3.86 & 3.44 \\
\hline$\%$ divorced individuals & 15.39 & 16.35 & 16.92 & 17.58 & 15.62 & 16.3 \\
\hline$\%$ others & 0.2 & 0.1 & 0,03 & 0.17 & 0.03 & 0.07 \\
\hline
\end{tabular}


TABLE 1

COMPARISON OF THE TREATMENT GROUPS (CONTINUED)

\begin{tabular}{|c|c|c|c|c|c|c|}
\hline & S Standard Letter & + Framed Flyer & - Framed Flyer & $\frac{ \pm+ \text { Framed Flyer \& }}{\text { Plan }}$ & $\frac{\text { - Framed Flyer \& }}{\text { Plan }}$ & $\underline{\text { Control }}$ \\
\hline & $(1)$ & (2) & (3) & $(4)$ & (5) & (6) \\
\hline & \multicolumn{6}{|c|}{ PANEL B: BENEFICIARY-SPECIFIC CHILD-BENEFIT RELATED VARIABLES } \\
\hline $\begin{array}{l}\text { SYSTEM OF CHILD BENEFIT } \\
\% \text { category working or temporarily } \\
\text { unemployed }\end{array}$ & 26.31 & 27.02 & 26.39 & 26.36 & 26.77 & 25.47 \\
\hline$\%$ category deceased & 3.77 & 3.36 & 3.89 & 3.87 & 4.57 & 5.00 \\
\hline $\begin{array}{l}\% \text { category unemployed for less } \\
\text { than } 6 \text { months }\end{array}$ & 3.44 & 3.06 & 3.5 & 3.37 & 3.29 & 3.41 \\
\hline $\begin{array}{l}\% \text { category unemployed for more } \\
\text { than } 6 \text { months }\end{array}$ & 34.89 & 34.95 & 35.46 & 35.19 & 34.7 & 35.54 \\
\hline$\%$ category retired & 2.14 & 2.2 & 1.58 & 1.85 & 1.9 & 2.02 \\
\hline$\%$ category disabled & 8.98 & 8.85 & 9.07 & 9.29 & 8.81 & 8.41 \\
\hline$\%$ guaranteed child benefit & 7.08 & 7.54 & 6.93 & 6,87 & 6.68 & 6.92 \\
\hline $\begin{array}{l}\% \text { working for government } \\
\text { institutions }\end{array}$ & 13.39 & 13.03 & 13.19 & 13.2 & 13,28 & 13.22 \\
\hline SOCIAL SUPPLEMENT & & & & & & \\
\hline $\begin{array}{l}\% \text { beneficiaries receiving social } \\
\text { supplement }\end{array}$ & 37.63 & 37.12 & 37.14 & 37.51 & 37.11 & 37.16 \\
\hline \multicolumn{7}{|l|}{ NUMBER OF CHILDREN } \\
\hline$\%$ individuals with 0 children & 0.27 & 0.39 & 0.69 & 0.4 & 0.37 & 0.43 \\
\hline$\%$ individuals with 1 child & 59.3 & 59.1 & 59 & 60.24 & 60.39 & 60.95 \\
\hline$\%$ individuals with 2 children & 26.48 & 26.88 & 26.78 & 25.89 & 25.96 & 26.17 \\
\hline$\%$ individuals with 3 children & 9.55 & 9.18 & 9.27 & 9.02 & 9.62 & 8.81 \\
\hline$\%$ individuals with 4 children & 2.97 & 2.67 & 2.97 & 2.66 & 2.41 & 2.25 \\
\hline$\%$ individuals with $>4$ children & 1.44 & 1.78 & 1.29 & 1.78 & 1.25 & 1.39 \\
\hline \multicolumn{7}{|l|}{$\begin{array}{l}\text { NUMBER OF PAYMENTS SINCE } \\
\text { FEB } 2006\end{array}$} \\
\hline Average number of payments & 13.73 & 13.84 & 13.82 & 13.72 & 13.7 & 13.7 \\
\hline $\begin{array}{l}\text { Standard deviation of number of } \\
\text { payments }\end{array}$ & 4.73 & 4.64 & 4.69 & 4.78 & 4.75 & 4.76 \\
\hline
\end{tabular}


TABLE 1

COMPARISON OF THE TREATMENT GROUPS (CONTINUED)

\begin{tabular}{|c|c|c|c|c|c|c|}
\hline & $\frac{\text { Standard }}{\underline{\text { Letter }}}$ & + Framed Flyer & - Framed Flyer & $\frac{+ \text { Framed Flyer \& }}{\underline{\text { Plan }}}$ & $\frac{\text { - Framed Flyer \& }}{\underline{\text { Plan }}}$ & $\underline{\text { Control }}$ \\
\hline & $(1)$ & $(2)$ & (3) & $(4)$ & $(5)$ & (6) \\
\hline & \multicolumn{6}{|c|}{ PANEL C: BENEFICIARY-SPECIFIC RESIDENCE-RELATED CHARACTERISTICS } \\
\hline REGION & & & & & & \\
\hline$\%$ individuals living in Flanders & 32.75 & 32.38 & 32.35 & 32.29 & 32.09 & 32.3 \\
\hline \% individuals living in Wallonia & 54.39 & 54.69 & 54.75 & 54.81 & 55.13 & 54.62 \\
\hline$\%$ individuals living in Brussels & 12.85 & 12.93 & 12.9 & 12.9 & 12.78 & 13.08 \\
\hline \multicolumn{7}{|l|}{ PROVINCE } \\
\hline$\%$ individuals living in Antwerp & 9.28 & 9.43 & 9.27 & 9.27 & 9.27 & 9.28 \\
\hline$\%$ individuals living in Flemish Brabant & 5.08 & 4.96 & 4.86 & 5.04 & 4.98 & 5.09 \\
\hline$\%$ individuals living in Walloon Brabant & 3.25 & 3.10 & 3.20 & 3.32 & 3.34 & 3.30 \\
\hline$\%$ individuals living in Brussels & 12.92 & 13.17 & 12.95 & 13.01 & 13.01 & 12.93 \\
\hline$\%$ individuals living in West Flanders & 6.20 & 6.55 & 6.46 & 6.35 & 6.42 & 6.41 \\
\hline$\%$ individuals living in East Flanders & 7.25 & 6.97 & 7.32 & 7.10 & 7.08 & 7.12 \\
\hline$\%$ individuals living in Hainaut & 25.05 & 25.80 & 25.65 & 25.80 & 25.79 & 25.65 \\
\hline \% individuals living in Liège & 16.38 & 14.91 & 15.17 & 15.04 & 15.04 & 15.16 \\
\hline \% individuals living in Limburg & 4.19 & 4.38 & 4.41 & 4.38 & 4.35 & 4.38 \\
\hline$\%$ individuals living in Luxemburg & 3.92 & 3.98 & 3.91 & 3.90 & 3.93 & 3.96 \\
\hline$\%$ individuals living in Namur & 6.48 & 6.74 & 6.79 & 6.78 & 6.80 & 6.73 \\
\hline \multicolumn{7}{|l|}{ DEGREE OF URBANISATION } \\
\hline $\begin{array}{l}\% \text { of individuals living in a metropolitan } \\
\text { city }\end{array}$ & 18 & 18 & 18.27 & 17.74 & 18.03 & 17.75 \\
\hline $\begin{array}{l}\% \text { of individuals living in an urban } \\
\text { agglomeration }\end{array}$ & 18.3 & 18.56 & 18.44 & 18.45 & 18.6 & 18.35 \\
\hline$\%$ of individuals living in the suburbs & 8.75 & 8.72 & 8.71 & 8.75 & 8.57 & 8.71 \\
\hline$\%$ of individuals living in a regional city & 13.29 & 13.66 & 13.29 & 13.3 & 13.18 & 13.22 \\
\hline$\%$ of individuals living in a small city & 19.63 & 19.35 & 19.16 & 19.39 & 19.08 & 19.71 \\
\hline$\%$ of individuals living in rest & 12.39 & 12.21 & 12.57 & 12.39 & 12.74 & 12.62 \\
\hline $\begin{array}{l}\% \text { of individuals living in a commuting } \\
\text { town }\end{array}$ & 9.65 & 9.51 & 9.56 & 9.97 & 9.79 & $9 . .64$ \\
\hline
\end{tabular}


TABLE 1

COMPARISON OF THE TREATMENT GROUPS (CONTINUED)

\begin{tabular}{|c|c|c|c|c|}
\hline Standard Letter & + Framed Flyer & - Framed Flyer & $\frac{+ \text { Framed Flyer \& }}{\text { Plan }}$ & $\frac{- \text { Framed Flyer \& }}{\text { Plan }}$ \\
\hline (1) & (2) & (3) & (4) & (5) \\
\hline
\end{tabular}

PANEL D. EFFECTS ON COMPLIANCE

Percentage of Beneficiaries who Switched

Net Percentage of Beneficiaries

who Switched

23.97

18.54

2,995
26.06

20.63

$2,3.039$
26.12

20.69

3,032
28.32

22.89

2,970
27.35

22.92

2,951
5.43

-

3,019

Note: We stratified the sample according to: language and age category of the beneficiary, total number of children for which beneficiary receives child benefit support, whether the beneficiary receives a social supplement, status type of the 'entitled individual' linked to the beneficiary, and region, province, degree of urbanization of

beneficiary's residence. We have a total of 3,284 or 3,285 possible observations per group. Deviations from this are accounted for by attrition between April and June, by our sample restriction decision to exclude beneficiaries who had not yet received more than one payment and by the exclusion of German beneficiaries, beneficiaries who had mistakenly received two mailings and by missing data. 
FIGURE 1

EVolution OF the PERCENTAge BENEFICIARIES PAID BY CHEQUE BETWEEN FEBRUARY 2006 AND DECEMBER 2007

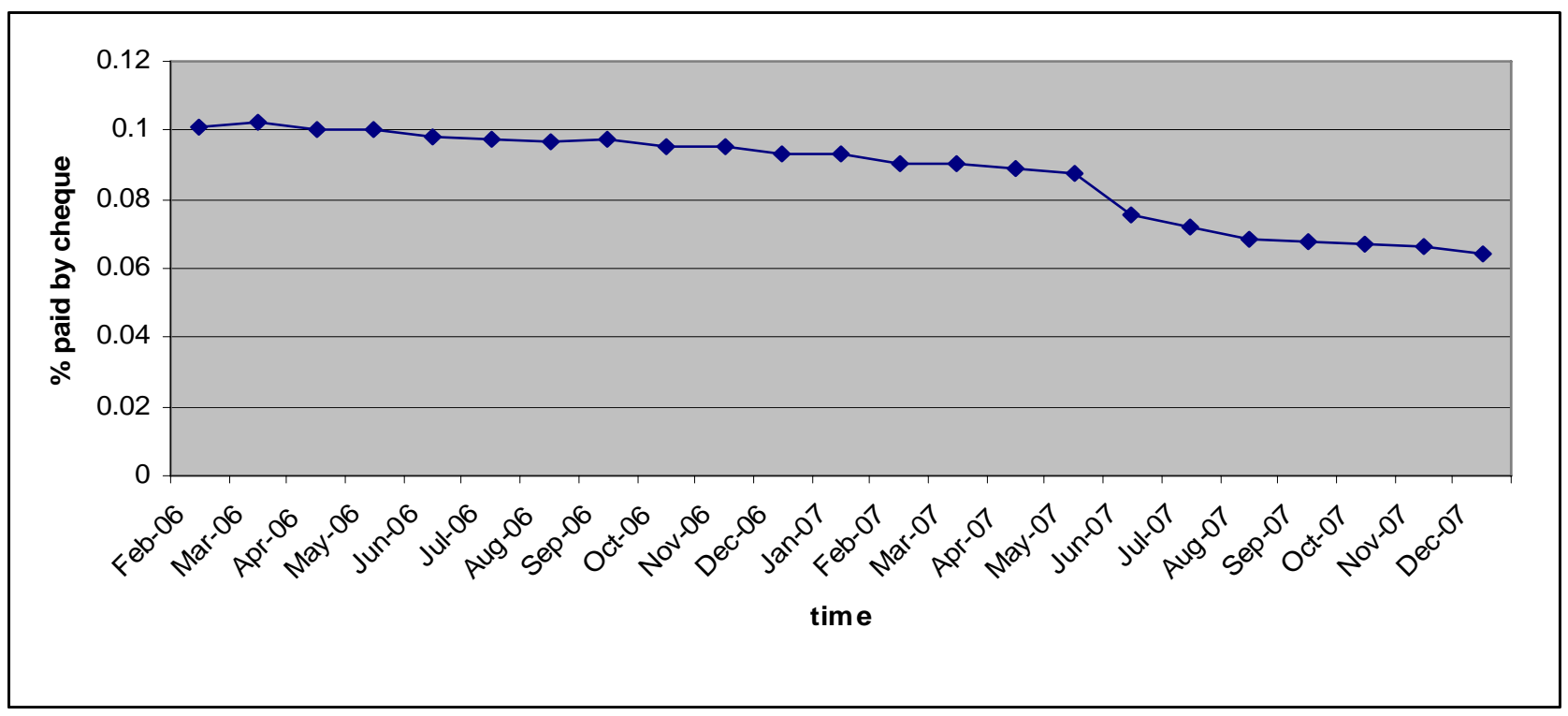

TABLE 2

LINEAR REgRESSION MODELS: PREDICTING OVERALL PERCENTAGE BENEFICIARIES PAID BY CHEQUE OVER TIME

\begin{tabular}{|c|c|c|c|c|c|c|c|c|}
\hline & \multicolumn{2}{|c|}{ No step function } & \multicolumn{2}{|c|}{$\begin{array}{l}\text { Step function: March } \\
2007\end{array}$} & \multicolumn{2}{|c|}{$\begin{array}{l}\text { Step function: June } \\
2007 \\
\end{array}$} & \multicolumn{2}{|c|}{$\begin{array}{l}\text { Step function: June } \\
\text { and August } 2007\end{array}$} \\
\hline & Coeff. & S.e. & Coeff. & S.e. & Coeff. & S.e. & Coeff. & S.e. \\
\hline TIME & -0.183 & $(0.015)^{\star \star \star}$ & -0.157 & $(0.029)^{\star \star \star}$ & -0.097 & $(0.067)^{\star \star \star}$ & -0.092 & $(0.005)^{\star \star \star}$ \\
\hline MARCH 2007 & & & -0.409 & $(0.387)$ & & & & \\
\hline JUNE 2007 & & & & & -1.558 & $(0.100)^{\star \star \star}$ & -1.341 & $(0.080)^{\star \star \star}$ \\
\hline AUGUST 2007 & & & & & & & -0.388 & $(0.077)^{\star \star \star}$ \\
\hline Constant & 10.924 & $(0.202)^{\star \star \star}$ & 10.790 & $(0.238)^{\star \star \star}$ & 10.376 & $(0.067)^{\star \star \star}$ & 10.333 & $(0.046)^{\star \star \star}$ \\
\hline $\mathrm{R}^{2}$ & \multicolumn{2}{|c|}{0.880} & \multicolumn{2}{|c|}{0.886} & \multicolumn{2}{|c|}{0.991} & \multicolumn{2}{|c|}{0.996} \\
\hline
\end{tabular}

Note: Data hails from the National Office for Family Benefits; monthly statements of share of its Clients paid by check from February 2006 until December 2007. 
FIGURE 2

OBSERVED AND PREDICTED PERCENTAGE BENEFICIARIES PAID BY CHEQUE FOR DIFFERENT REGRESSION MODELS
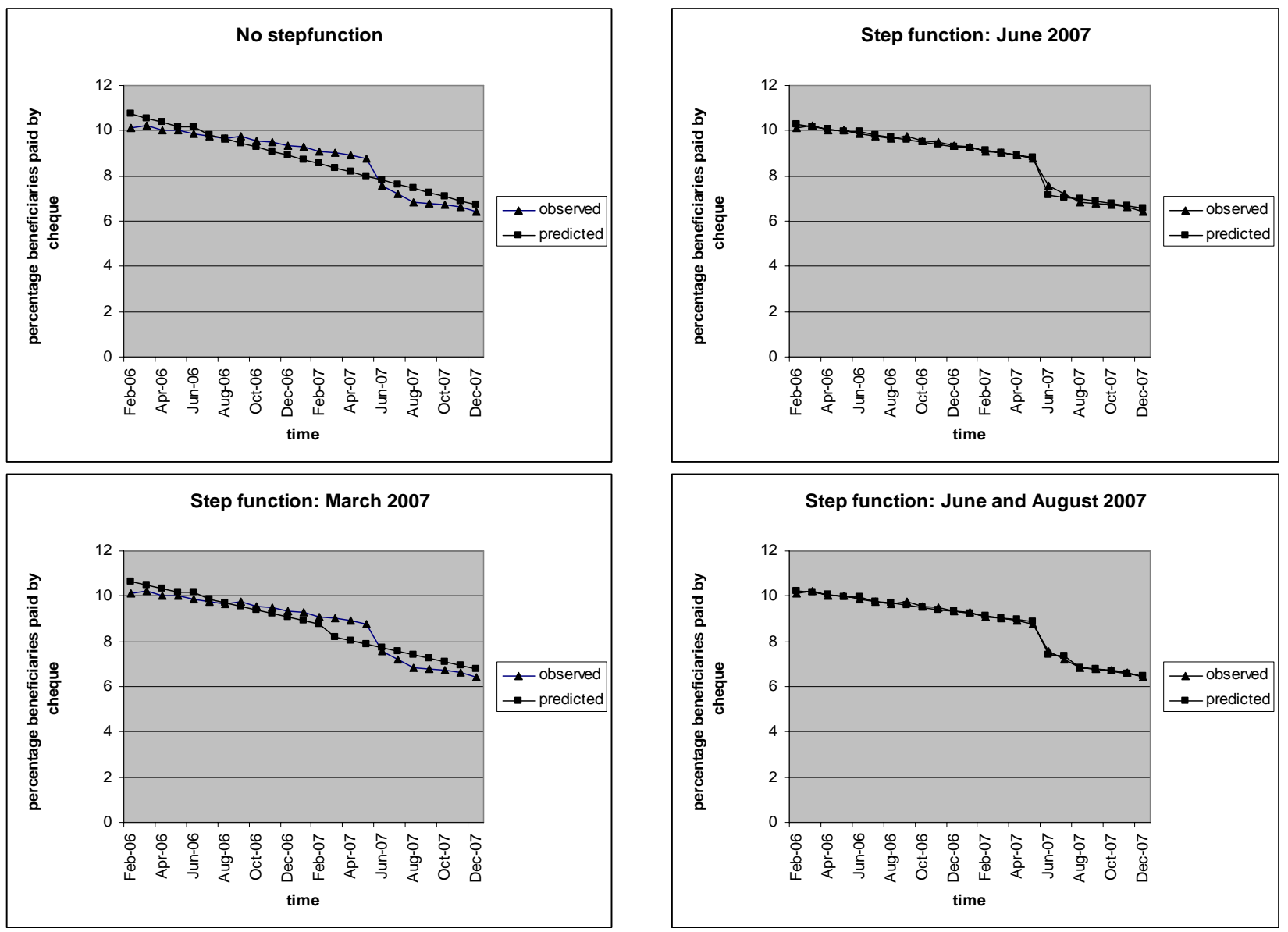
TABLE 3

REDUCED FORM ESTIMATES (OLS) - EFFECTS OF TREATMENTS ON SWITCHING RATE

\begin{tabular}{|c|c|c|}
\hline & Coefficient & Standard Error \\
\hline \multicolumn{3}{|l|}{ TREATMENTS ${ }^{B}$} \\
\hline Standard letter & 0.178 & $(0.009)^{\star \star \star}$ \\
\hline + Framed Flyer & 0.201 & $(0.009)^{\star \star *}$ \\
\hline - Framed Flyer & 0.202 & $(0.009)^{\star \star \star}$ \\
\hline + Framed Flyer Plus Specific Plan & 0.223 & $(0.009)^{\star \star \star}$ \\
\hline - Framed Flyer Plus Specific Plan & 0.229 & $(0.009)^{\star \star \star}$ \\
\hline Sex of the beneficiary ${ }^{B}$ & -0.03 & $(0.011)^{\star \star \star}$ \\
\hline \multicolumn{3}{|l|}{ AGE OF THE BENEFICIARY ${ }^{B}$} \\
\hline$<18$ & -0.137 & $(0.033)^{\star \star \star}$ \\
\hline $18-20$ & -0.045 & $(0.018)^{\star \star}$ \\
\hline $21-24$ & -0.027 & $(0.013)^{\star \star}$ \\
\hline $25-34$ & -0.011 & $(0.007)$ \\
\hline $45-54$ & 0.006 & $(0.009)$ \\
\hline $55-64$ & 0.011 & $(0.017)$ \\
\hline$>64$ & 0.019 & $(0.023)$ \\
\hline FOREIGN & 0.035 & $(0.013)^{\star \star \star}$ \\
\hline FOREIGNH * TREATED & 0.029 & $(0.014)^{\star \star}$ \\
\hline \multicolumn{3}{|l|}{ MARITAL STATUS OF THE BENEFICIARYB } \\
\hline Married & 0.041 & $(0.008)^{\star \star \star}$ \\
\hline Widow(er) & 0.059 & $(0.020)^{\star}$ \\
\hline Divorced & 0.033 & $(0.010)^{\star \star \star}$ \\
\hline Other & 0.143 & $(0.111)$ \\
\hline Employed & 0.031 & $(0.007)^{\star \star \star}$ \\
\hline \multicolumn{3}{|l|}{ SYSTEM OF CHILD BENEFIT ${ }^{B}$} \\
\hline Category orphans & -0.029 & $(0.019)$ \\
\hline Category unemployed $<6$ months & -0.004 & $(0.019)$ \\
\hline Category unemployed $>6$ months & -0.037 & $(0.011)^{\star \star \star}$ \\
\hline Category retired & 0.003 & $(0.025)$ \\
\hline Category invalidity & -0.052 & $(0.000)^{\star \star \star}$ \\
\hline Guaranteed child benefit & 0.032 & $(0.017)^{\star \star}$ \\
\hline Government institutions & 0.011 & $(0.011)$ \\
\hline Recipient of a Social Supplement & 0.048 & $(0.009)^{\star \star \star}$ \\
\hline Number of payments since February 2006 & -0.008 & $(0.0007)^{\star \star \star}$ \\
\hline Constant & 0.135 & $(0.042)^{\star \star \star}$ \\
\hline Number of observations & & \\
\hline Adjusted $\mathrm{R}^{2}$ & & \\
\hline
\end{tabular}

Note: The regression controls for all the stratification variables. None of the residence-related variables significantly predicted beneficiaries' switching decision. B: Reference categories: treatment: control group; sex of beneficiary: female; age of beneficiary: 35-44; foreign: Belgian; marital status beneficiary: unmarried; system of child benefit: category

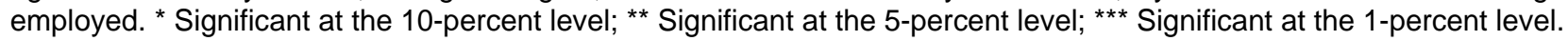


TABLE 4

PROBIT REGRESSION: PREDICTING EARLY VERSUS LATE SWITCH Coefficient

Standard Error

Treatments

+ Framed Flyer

0.027

0.009

0.184

- Framed Flyer

0.035

+ Framed Flyer + Specific Plan

0.043

0.019

- Framed Flyer + Specific Plan

$(0.018)^{\star \star}$

Number of observations

$(0.018)^{\star \star}$

Adjusted $\mathrm{R}^{2}$

4,884

0.03

Note: The regression controls for all the stratification varialbes. The reference category of the dependent variable is early change (change of payment method in April). B: Reference category: Treatment: Standard letter. ${ }^{*}$ Significant at the 5percent level. 
Comment pouvez-vous faire payer désormais vos allocations familiales sur votre compte?

Les allocations familiales ne peuvent être payées que sur un compte à votre nom ou sur un compte commun (à votre nom et à celui de votre partenaire) auquel vous avez aussi accès.

Vous avez déjà un compte?

I. Complétez vous-même la partie supérieure du formulaire ci-joint en mentionnant votre adresse, votre date de naissance et votre numéro national (vous le trouverez en haut à droite de votre carte SIS).

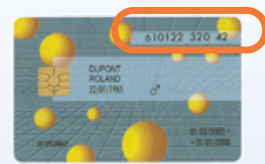

2. Faites compléter la partie inférieure par votre banque.

3. Renvoyez le formulaire au service et à l'adresse qui sont indiqués sur ce formulaire.

Vous n'avez pas encore de compte? Vous pouvez ouvrir un compte dans n'importe quelle banque pour I 2 EUR au maximum par an.

\section{Plus d'info?}

Avez-vous d'autres questions concernant votre dossier?

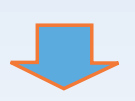

Prenez contact avec votre gestionnaire de dossier.

Vous trouverez son nom, son service, son adresse et son numéro de téléphone sur le formulaire ci-joint.

Vous désirez des informations générales?

Prenez contact avec:

L'Office national d'allocations familiales pour travailleurs salariés

Rue de Trèves 70

1000 BRUXELLES

Tél. 02-237 2320

ou 0800-94 434 (numéro gratuit)

info.mediation@rkw-onafts.fgov.be www.allocationfamiliale.be

\section{FAITES VERSER VOS}

\section{ALLOCATIONS FAMILIALES}

\section{SUR UN COMPTE BANCAIRE !}

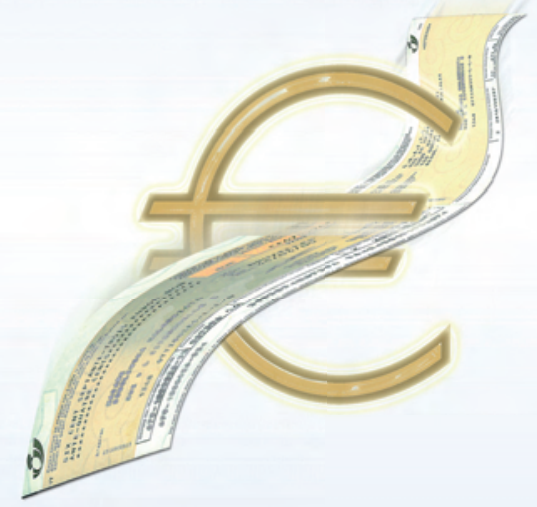

Le pajement sur un

compte est:

$\Rightarrow$ gratuit

$\Rightarrow$ Sû?

$\Rightarrow$ pratique

$\Rightarrow$ facille à contrôler 


\section{Pourquoi faire payer vos}

allocations familiales sur un compte bancaire?

Vous recevez actuellement vos allocations familiales par chèque circulaire.

Le paiement sur un compte bancaire présente toutefois de nombreux AVANTAGES:

\section{- il est gratuit}

- il est beaucoup plus sûr (un chèque circulaire peut se perdre ou être volé)

- vous pouvez retirer votre argent où et quand vous le voulez, et le montant que vous souhaitez

- vous contrôlez aisément vos revenus et vos dépenses

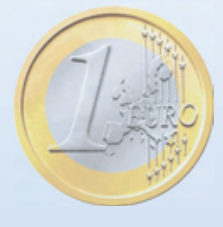

Pourquoi opter maintenant pour le paiement de vos allocations familiales sur un compte bancaire?

Deux initiatives récentes du gouvernement rendent le paiement sur un compte bancaire ENCORE PLUS AVANTAGEUX:

I. Grâce à la loi instaurant un service bancaire de base, chaque personne disposant d'un domicile légal en Belgique peut ouvrir un compte pour I 2 EUR par an au maximum.

2. Depuis le Ier janvier 2007, les allocations familiales qui sont versées sur un compte ne peuvent plus être saisies le jour du versement. Les allocations familiales sont normalement versées sur votre compte au plus tard le 10 du mois.

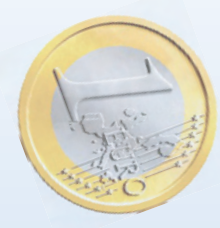

\section{Attention:}

- Vos allocations familiales ne sont protégées entièrement contre la saisie que le jour du versement sur votre compte. Ensuite, la protection diminue d' $1 / 30$ par jour.

Exemple: les allocations familiales, d'un montant de I 20 EUR, sont versées sur votre compte le 10 juin. Le 10 juin, le montant est entièrement protégé contre la saisie.

Un jour plus tard, le I I juin, 4 EUR peuvent déjà être saisis (I/30 de I20 EUR). Le 20 juin, 40 EUR peuvent être saisis (I0/30 de I 20 EUR).

- Vos allocations familiales ne sont pas protégées contre la saisie si vous les touchez d'abord au moyen d'un chèque circulaire et que vous les versez seulement ensuite sur votre compte.

- Votre banque peut apurer un solde négatif sur votre compte. 